\title{
Response of maize to nitrogen levels and seed priming
}

\author{
Murad Ali ${ }^{1}$, Zia Ullah ${ }^{2 *}$, Ishaq Ahmad Mian ${ }^{3}$, Naseem Khan ${ }^{3}$, Nangial \\ $\mathrm{khan}^{4}$, Muhammad Adnan ${ }^{5}$ and Muhammad Saeed ${ }^{1}$ \\ 1. Cereal Crops Research Institute (CCRI), Pirsabak, Nowshera, Pakistan. \\ 2. Department of water management, The University of Agriculture, Peshawar, Pakistan \\ 3. Department of soil and environmental sciences, University of Agriculture, Peshawar, Pakistan \\ 4. Department of Agronomy, The University of Agriculture, Peshawar, Pakistan \\ 5. Department of Agriculture, University of Swabi, Pakistan \\ *Corresponding author's email: nziakhan23@gmail.com \\ Citation
}

Murad Ali, , Zia Ullah, Ishaq Ahmad Mian, Naseem Khan, Nangial khan, Muhammad Adnan and Muhammad Saeed. Response of maize to nitrogen levels and seed priming. Pure and Applied Biology. Vol. 5, Issue 3, pp 578587. http://dx.doi.org/10.19045/bspab.2016.50075

\begin{tabular}{llll}
\hline \hline Received: 01/01/2016 & Revised: 03/06/2016 & Accepted: 07/06/2016 & Online First: 17/06/2016 \\
\hline \hline
\end{tabular}

\section{Abstract}

A field experiment was conducted to measure the impact of seed priming and nitrogen levels on maize yield and nitrogen uptake. Research was carried out in randomized complete block design with three replications at The University of Agriculture, Peshawar, Pakistan. Nitrogen at the rate of 0,75 and $150 \mathrm{~kg} \mathrm{ha}^{-1}$ were applied at three split doses, such as at sowing, knee and tasseling stage along with dry seed, water soaked and seed primed with potassium di-hydrogen phosphate $\left(\mathrm{KH}_{2} \mathrm{PO}_{4}\right)$ at the rate of $0.2 \%$ Phosphorous concentration. Seeds were soaked for 12 hours and then air dried for 30 minutes. Maize biological yield, grain yield, Stover yield, grains per cob, thousand grain weights, harvest index and total $\mathrm{N}$ uptake were significantly $(\mathrm{P} \leq 0.05)$ affected by seed priming and nitrogen levels. Maximum values of mentioned parameter were recorded at 150 $\mathrm{kg} \mathrm{N} \mathrm{ha}^{-1}$ in seeds primed with $0.2 \%$ phosphorous solution. Minimum values of all parameters were noted for control. P priming enhanced total $\mathrm{N}$ uptake by $34 \%$ than the dry seed. . Thus it is concluded that use of nitrogen at $150 \mathrm{~kg} \mathrm{ha}^{-1}$ along with $0.2 \% \mathrm{P}$ priming gives maximum maize yield and high $\mathrm{N}$ uptake.

Key words: Phosphorous; Biological yield; AB-DTPA; RCB (randomized complete block); DM

\section{Introduction}

Maize (Zea mays L.) is a cereal exhaustive crop used for many purpose such as a food for humans, feed for livestock and raw material for industries [1].On the basis of area and production within the cereals maize occupied $3^{\text {rd }}$ position after the wheat and rice in Pakistan, while it come on $2^{\text {nd }}$ after wheat in Khyber Pakkhtunkhwa. During the year 2012-2013 it was cultivated on 1,060 thousand hectares area with total production was 4,220thousand tons in Pakistan and in same year it was cultivated on 440.60 thousand hectares area and there total production was 833.56 thousand tons in KPK [2].

To increase the yield of cereal crops nitrogen play a very imperative role because it promotes strong vegetative growth and produced deep green colour[3].Nitrogen have many function in plant body like it is a major constituent of amino acids, building blocks of 
proteins and also part of DNA,RNA and nucleic acid[4]. According to an estimate 1 to $4 \%$ of the plant dry matter is consist of nitrogen, which is an essential macro nutrient [2]. Sufficient availability of nitrogen throughout the growing season is essential for plant growth processes such as production of chlorophyll and many enzymes and also mediates the utilization of potassium, phosphorus and many other elements in plants [5]. Nitrogen plays a vital role in physiological status of plant.

Nitrogen deficiency or excess can reduced the yield of maize and utilization of other plant nutrients. Nitrogen fertilizers requirement for maize varies with cultivars and environmental condition but however, maize nitrogen requirement as high as 150 $200 \mathrm{~kg} \mathrm{~N} \mathrm{ha}^{-1}[6]$. According to an estimate the application of nitrogen fertilizer will increase maize yield by 60-70 percent in year 2025 and two-third of this will be applied in developing world [7].

Seed soaking is recommended to enhance the production in many parts of the world. The primed seed have used by the farmer in past to fill gapes [8]. Seed priming is the soaking of seed then drying back to storage moisture [9]. Seed priming is simple, economical process safe and sound to the environment [10]. Several researcher established that seed soaking have a lot of advantages such as early and rapid emergence, higher water use efficiency, deeper roots, uniformity in emergence, increasing in root growth, break of seed dormancy, germination in wide range of temperature, reproductive organ initiation, early flowering and maturity, resistance to environmental stresses (drought and salinity) and diseases (Sclerotium rolfsii L.): Higher grain yield in wheat (Triticum aestivum L.) [11] and maize (Zea mays L.) [12]. Seed of wheat primed with $\mathrm{P}$ increase emergence $\mathrm{m}^{-}$ ${ }^{2}$, tiller $\mathrm{m}^{-2}$, grains spike $^{-1}$, thousand grain weight and grain yield as compared to nonprimed seed [1]. It is confirmed that seed soaking with a $1 \%$ phosphorous solution using $\mathrm{KH}_{2} \mathrm{PO}_{4}$ enhanced fertilizer use efficiency and increased yield and profit for different crops which is grown on phosphorous deficient soil [13]. Therefore the present experiment was designed to evaluate the effect of nitrogen levels and seed priming on yield and yield component of maize and their uptake of $\mathrm{N}$ under the semi-arid of climatic condition.

\section{Materials and methods Experimental Site}

The experiment was conducted at the New Developmental Farm (NDF) Khyber Pakhtunkhwa, the University of Agriculture, Peshawar, Pakistan during 2013. Peshawar under Koppen's climate classification features has a semi-arid climate with very hot summers and mild winters. It is located at $34^{\circ} 01^{\prime} \mathrm{N}$ and $71^{\circ} 35^{\prime} \mathrm{E}$. The Physico-chemical characteristics of the experimental site are given in Table1.

\section{Experimental design and treatments:}

Two factorial RCB design with three replications was used and plot size was kept $4.5 \mathrm{~m} \times 4 \mathrm{~m}$. The experiment was consisted of two factors including three nitrogen levels $(0$, $75,150 \mathrm{~kg} \mathrm{ha}^{-1}$ ) applied at three split doses such as (sowing, knee stage, tasseling stage) and three seed priming such as (dry, water soaked and $0.2 \% \mathrm{P}$ soaked seed using $\mathrm{KH}_{2} \mathrm{PO}_{4}$ ). Seed per plot was sealed in perforated plastic bags and the bags were soaked in distilled water and aqueous solution of $\mathrm{P}$ for 12 hours. After soaking, bags were removed, drained and then surface dried in shade for around half an hour to facilitate clump-free sowing using maize variety Azam with seed rate of $40 \mathrm{~kg} \mathrm{ha}^{-1}$. Urea was used as sources of nitrogen and SSP was used as sources of P. Phosphorous were used at the rate of $100 \mathrm{~kg} \mathrm{ha}^{-1}$ at sowing time. 
Table 1. Physio- chemical characteristics of the soil under study

\begin{tabular}{|c|c|c|}
\hline Property & Units & Concentration \\
\hline Sand & $\%$ & 41.4 \\
\hline Silt & $\%$ & 51.4 \\
\hline Clay & $\%$ & 7.2 \\
\hline Textural class & - & Silt loam \\
\hline $\mathrm{pH}(1: 5)$ & - & 7.61 \\
\hline Electrical conductivity(EC) & $\mathrm{d} \mathrm{Sm}^{-1}$ & 1.12 \\
\hline Lime & $\%$ & 15.3 \\
\hline Organic matter content & $\%$ & 0.9 \\
\hline Total nitrogen content & $\%$ & 0.1 \\
\hline Bulk density & $\mathrm{gm} \mathrm{cm}^{-3}$ & 1.35 \\
\hline AB-DTPA extractable P & $\mathrm{mg} \mathrm{kg}^{-1}$ & 2.14 \\
\hline
\end{tabular}

\section{Statistical analysis}

Analysis of variance procedure was followed for the statistical analysis of recorded data according to the design used. Means was compared using least significant differences test at $\mathrm{P} \leq 0.05$ upon significant F-test [14].

\section{Results and discussion}

\section{Biological yield $\left(\mathrm{kg} \mathrm{ha}^{-1}\right)$}

Biological yield represent total amount of above ground biomass accumulated by the plant. Data regarding the biological yield of maize are given in (Table 2). Analysis of the data showed that nitrogen levels and seed priming significantly $(\mathrm{P} \leq 0.05)$ affected biological yield of maize. Biological yield increase $\left(4788 \mathrm{kgha}^{-1}\right)$ with application of $150 \mathrm{~kg} \mathrm{~N} \mathrm{ha}^{-1}$ as compare to control $(0 \mathrm{~kg} \mathrm{~N}$ $\mathrm{ha}^{-1}$ ) similarly seed priming also improved biological yield, Biological yield was increased (1126 kg ha-1) with P primed seed as compare to non-primed seed (control). The interaction between priming and nitrogen revealed that increased the levels of nitrogen the biological yield increased, all the three lines were linearly increased but the maximum biological yield showed by priming line $(0.2 \% \mathrm{P})$ (Fig. 1). These results are similar with the finding of [15] and [16] whose reported that the different levels of nitrogen increased significantly the biological yield of maize. [17] and [18] reported that primed seed significantly increased the total biomass

And dry weight as compared to control.

Grain yield (kg ha-1)

Grain yield is significantly increased with nitrogen levels and seed priming. grain yield was increased (1864 $\left.\mathrm{kg} \mathrm{ha}^{-1}\right)$ with application of $150 \mathrm{~kg} \mathrm{~N} \mathrm{ha}^{-1}$ as compared to control with $0 \mathrm{~kg} \mathrm{~N} \mathrm{ha}{ }^{-1}$ similarly Seed priming enhanced the grain yield. The seed which was soaked with P solution increased grain yield $(576 \mathrm{~kg}$ $\mathrm{ha}^{-1}$ ) as compare to non-primed seed. The interaction of nitrogen and priming significantly affect the grain yield. According to (Figure. 2) increase in the nitrogen levels linearly increased the grain yield and the maximum grain yield was showed by seed priming $(0.2 \% \mathrm{P})$. Similar result was also reported by [19] and [20] respectively. Seed priming with water is also effective for increasing the maize yield [21]. 
Ali et al.

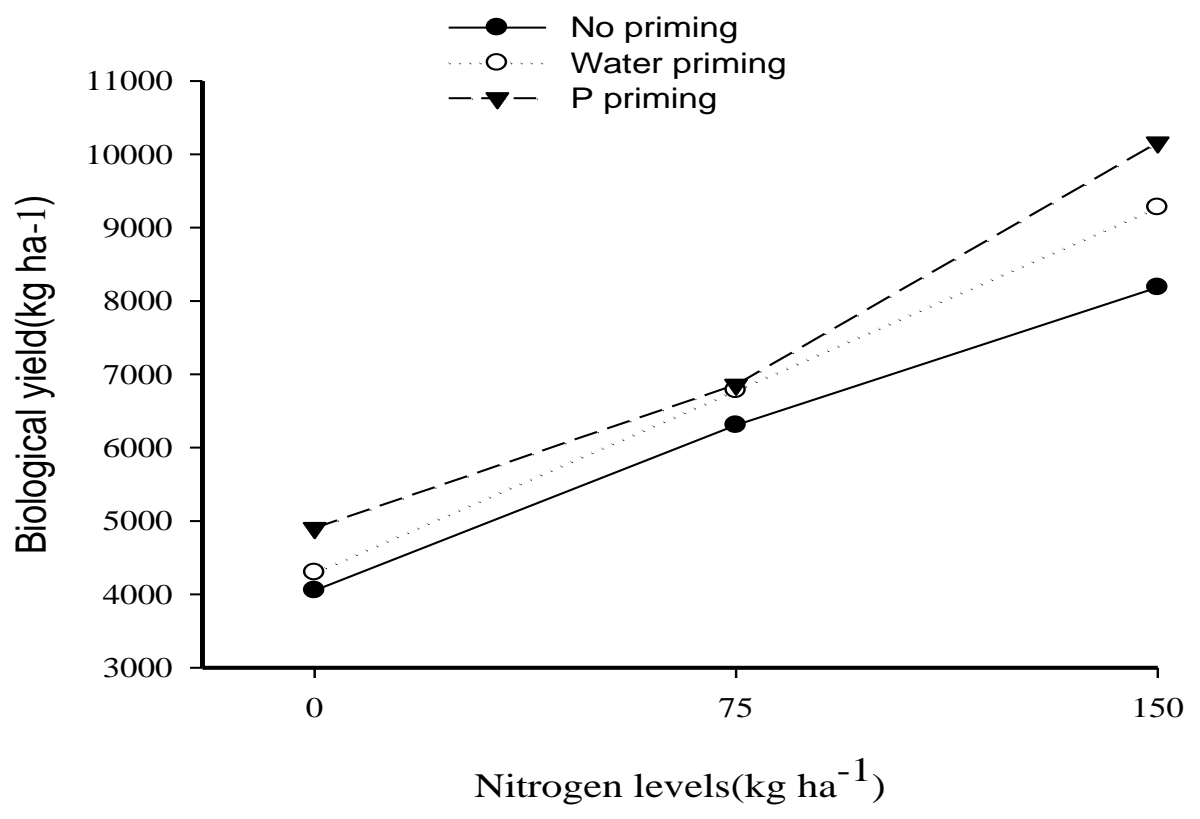

Figure1. Biological yield of maize as influenced by interaction of nitrogen levels and seed priming

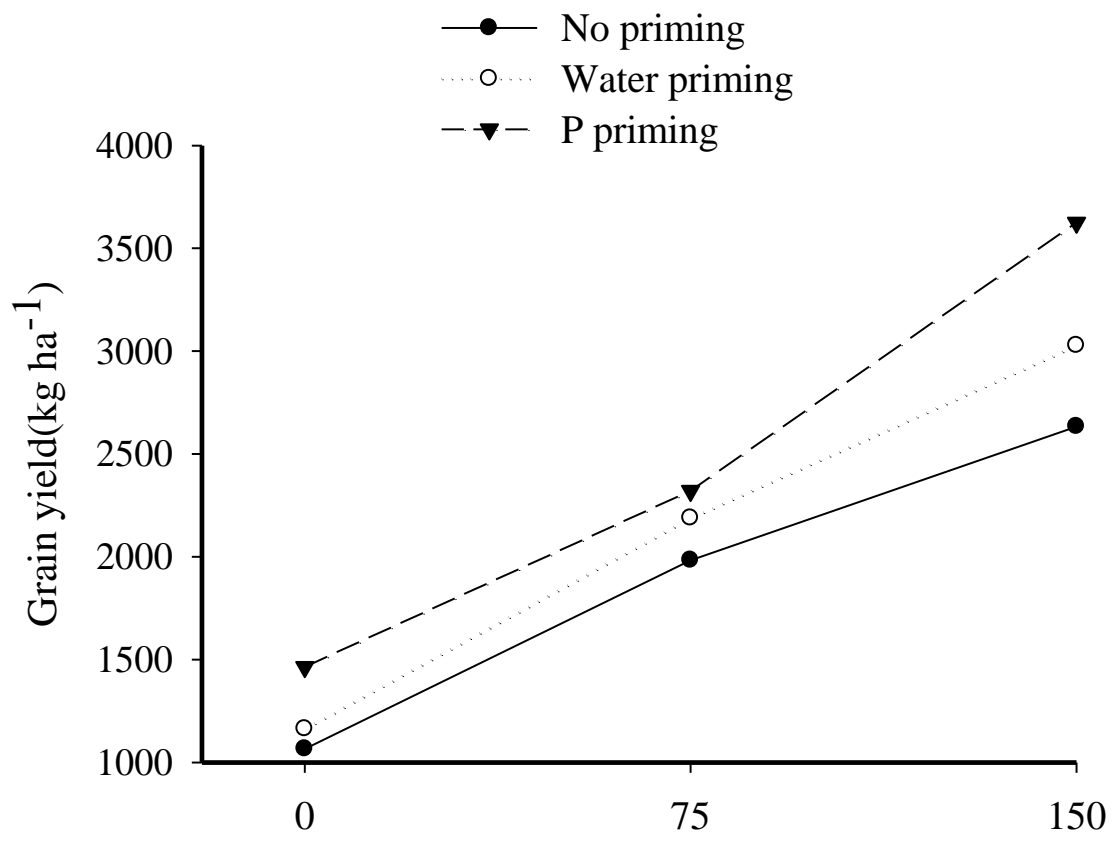

Nitrogen levels $\left(\mathrm{kg} \mathrm{ha}^{-1}\right)$

Figure 2. Grain yield of Maize as influenced by interaction of nitrogen levels and seed priming. 


\section{Stover yield (kg ha $\left.{ }^{-1}\right)$}

Stover yield is given in Table 2 data showed that nitrogen levels and seed priming significantly $(\mathrm{P} \leq 0.05)$ increase the Stover yield of maize. But interaction was found non-significant. As increased the levels of nitrogen Stover yield was increased. The maximum yield was recorded at those plots which was treated with $150 \mathrm{~kg} \mathrm{~N} \mathrm{ha}^{-1}(6112$ $\mathrm{kg} \mathrm{ha}^{-1}$ ) while minimum yield was obtained at $0 \mathrm{~kg} \mathrm{~N} \mathrm{ha}^{-1}\left(3188 \mathrm{~kg} \mathrm{ha}^{-1}\right)$. According to the mean table maximum Stover yield was recorded by $\mathrm{P}$ priming (4838 $\mathrm{kg} \mathrm{ha}^{-1}$ ) while the lower yield was noted it control plot $\left(4288 \mathrm{~kg} \mathrm{ha}^{-1}\right)$. These results are highly corelated with [22]. P primed and water soaked seed results are higher from control and these result are highly related with the result founded by [23] who reported that when seed primed with $0.2 \% \mathrm{P}$ solution enhanced the straw yield also mentioned that seed priming increase $94 \% \mathrm{DM}$ when primed with $1 \% \mathrm{P}$ solution as compared to control

Table 2. Biological yield ( $\left.\mathrm{kg} \mathrm{ha}^{-1}\right)$, Grain yield $\left(\mathrm{kg} \mathrm{ha}^{-1}\right)$ and Stover yield of maize as influenced by seed priming and nitrogen levels

\begin{tabular}{|l|c|c|c|}
\hline $\begin{array}{l}\text { Nitrogen } \\
(\mathbf{k g ~ h a}\end{array}$ & $\begin{array}{l}\text { Biological yield } \\
(\mathbf{k g ~ h a}\end{array}$ & $\begin{array}{l}\text { Grain yield } \\
\left(\mathbf{k g ~ h a}^{-1}\right)\end{array}$ & Stover yield $\mathbf{k g ~ h a}^{-\mathbf{1}} \mathbf{)}$ \\
\hline 0 & $4419 \mathrm{c}$ & $1231 \mathrm{c}$ & $3188 \mathrm{c}$ \\
\hline 75 & $6650 \mathrm{~b}$ & $2164 \mathrm{~b}$ & $4486 \mathrm{~b}$ \\
\hline 150 & $9207 \mathrm{a}$ & $3095 \mathrm{a}$ & $6112 \mathrm{a}$ \\
\hline L.S.D0.05 & 119.2 & 29.5 & 96.6 \\
\hline Seed priming & - & - & - \\
\hline No priming & $6182 \mathrm{c}$ & $1894 \mathrm{c}$ & $4288 \mathrm{c}$ \\
\hline Water priming & $6786 \mathrm{~b}$ & $2126 \mathrm{~b}$ & $4660 \mathrm{~b}$ \\
\hline P priming & $7308 \mathrm{a}$ & $2470 \mathrm{a}$ & $4838 \mathrm{a}$ \\
\hline Interaction N $\times$ Priming & $*$ Fig 1 & *Fig 2 & $\mathrm{NS}$ \\
\hline
\end{tabular}

Mean followed by different letters in each column are differ from each other significantly,

$\mathrm{NS}=$ non-significant.

“*” = Significant at 0.05 percent

\section{Grains cob $^{-1}$}

The data grains per cob are shown in Table 3. Statistical analysis of data indicated that the levels of nitrogen and seed priming significantly $(\mathrm{P} \leq 0.05)$ effect grains $\mathrm{cob}^{-1}$. The number of grains per cob was increased (67) at $150 \mathrm{~kg} \mathrm{~N} \mathrm{ha}^{-1}$ as compared to $0 \mathrm{~kg} \mathrm{~N}$ ha $^{-1}$ (control) similarly seed priming improved grains $\mathrm{cob}^{-1}$ maximum grains $\mathrm{cob}^{-1}$ was noted for P priming treatment and lower was on dry seed (control). Many researchers have founded increase in grains per pod in case of legumes or number of grains per cob in case of corn. Interactive effect of seed priming and nitrogen levels showed (Fig.3) results of water soaked and $\mathrm{P}$ priming were highly increased as compared to control but the high yield of grains per cob was showed by high nitrogen levels with $\mathrm{P}$ priming $(0.2 \% \mathrm{P})$. Our results are in line with the findings of [24] and [25] whose observed the similar increase or decrease effect on the parameter under discussion by the increase/decrease of dose of $\mathrm{N}$. these results are in line with the data of [26] reported that increasing the levels of $\mathrm{N}$ increase the number of grains $28 \%$ and the increase is occurred due to the increasing of leaf area index. As results showed that priming seed have higher number of grains per cob then followed by water soaked seed while minimum grains $\operatorname{cob}^{-1}$ obtained on dry seed. [23] had reported similar increase in number of grains $\mathrm{cob}^{-1}$ having studied priming of 
maize seed with phosphate solutions improves seedling growth and yield. Similarly [13] also noted similar increase in number of grains spike ${ }^{-1}$ of wheat primed with $0.3 \% \mathrm{P}$.

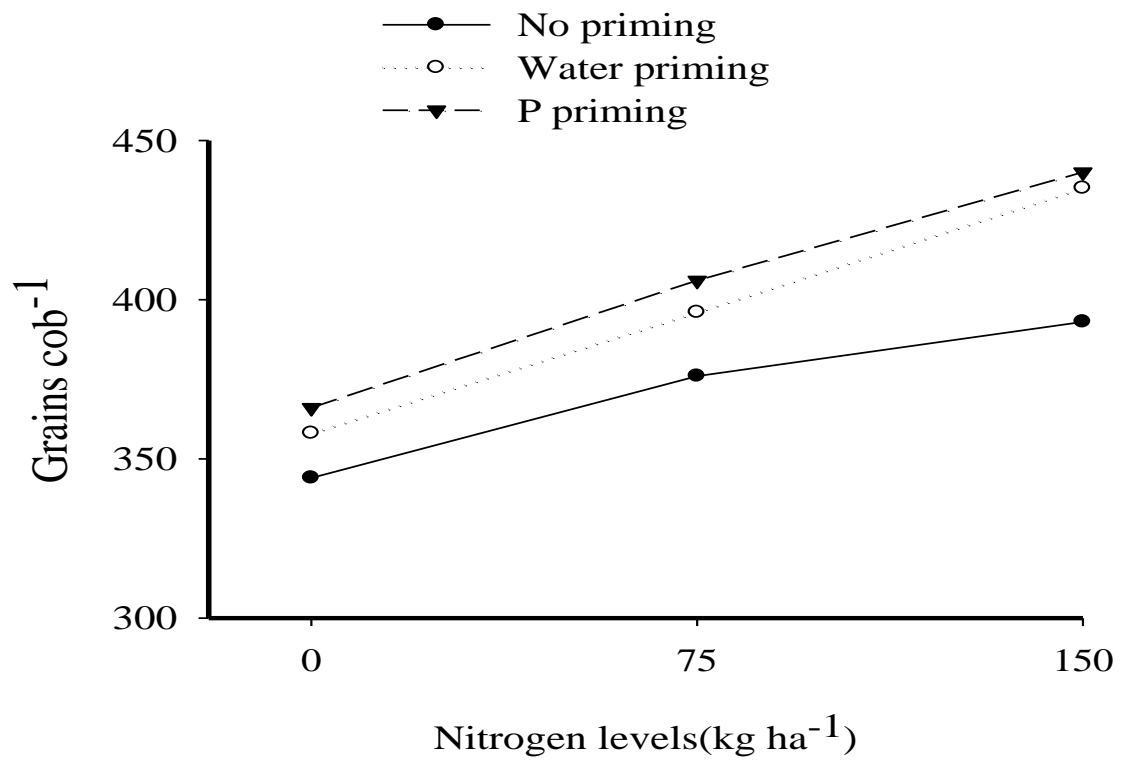

Figure 3. Grains per cob in maize as affected by interactive effect of nitrogen levels and seed priming

\section{Thousand grain weight (g)}

Significant differences were observed among the nitrogen levels and seed priming (Table3). Data Indicated that Thousands grains weight increased with increasing level of $\mathrm{N}$. maximum thousand grain weight was obtained at $150 \mathrm{~kg} \mathrm{~N} \mathrm{ha}^{-1}$ (290g) followed by $\mathrm{N}$ level of $75 \mathrm{~kg} \mathrm{ha}^{-1}(277 \mathrm{~g})$ While minimum thousand grain weight was recorded at $0 \mathrm{~kg}$ $\mathrm{N}$ ha $^{-1}(252 \mathrm{~g})$. Seed priming improved thousand grain weights. Higher thousand grain weight was recorded for $\mathrm{P}$ primed and water soaked seed (281 and $274 \mathrm{~g}$, respectively). Lower thousand grain weight was recorded for dry seed (265 g). The result are in agreement with [27] who reported that the maize varieties have a different response to different levels of nitrogen, more leaf area exposed by the canopy has resulted higher grains and its weight and this results is supported by[28]. Similarly priming also improved thousand grains weight and the result is highly co-related with the results reported by [23] and [17].

\section{Harvest index}

Data regarding harvest index of maize (Table 3) showed significant differences for mean effect of nitrogen levels, seed priming and non-significant variation for the interaction of nitrogen levels and seed priming. Maximum harvest index(34\%) was recorded in those plots which was applied $150 \mathrm{~kg} \mathrm{~N}^{-}$ ${ }^{1}$ followed (33\%) for $75 \mathrm{~kg} \mathrm{~N} \mathrm{ha}^{-1}$ while the minimum harvest index $(28 \%)$ was noted from those plots which have no nitrogen(control). Similarly higher harvest index $(33 \%)$ was recorded from the P primed seed followed by water soaked seed $(31 \%)$ and then dries seed (30\%). As harvest index was increased with increase in the rate of nitrogen, similar results were reported by [29], who stated that harvest index was significantly affected by nitrogen levels. As the seed priming effect on the harvest index was significant which was similar to the data recorded by [30] on effect of various priming sources on yield and yield components of maize cultivars and noted $60 \%$ of harvest 
index when seeds were primed with Polyethylene glycol. The results were also supported by [31] who reported that harvest index increased with $\mathrm{P}$ priming.

\section{Nitrogen uptake}

The total nitrogen uptake data are reported (Table 3) that seed priming and levels of nitrogen increase significantly $(\mathrm{P} \leq 0.05)$ the total uptake of nitrogen in maize crop. Mean value of data showed that the maximum uptake of nitrogen was recorded on $150 \mathrm{~kg} \mathrm{~N}$ $\mathrm{ha}^{-1}\left(201 \mathrm{~kg} \mathrm{~N} \mathrm{ha}^{-1}\right)$ then followed by $75 \mathrm{~kg} \mathrm{~N}$ $\mathrm{ha}^{-1}$ (129 $\mathrm{kg} \mathrm{N} \mathrm{ha}^{-1}$ ) and lower uptake were noted on control plot $\left(74 \mathrm{~kg} \mathrm{~N} \mathrm{ha}^{-1}\right)$.similarly the seed which was treated with $\mathrm{P}(0.2 \%)$ have maximum uptake of nitrogen $(155 \mathrm{~kg} \mathrm{~N}$ $\mathrm{ha}^{-1}$ ) while minimum uptake was noted on dry seed ( $112 \mathrm{~kg} \mathrm{~N} \mathrm{ha}^{-1}$ ). This may be due to increasing vegetative growth of crops which enhanced biological yield and enhanced total uptake by plant as compare to control which have no nitrogen. The interaction was also found significantly affected by nitrogen and priming. The total nitrogen uptake was high in $\mathrm{P}$ priming as increasing the levels of nitrogen (Fig.4). The results are highly corelated with the resulted observed by [32] similarly seed priming also enhanced uptake of nutrients and reported by [23] indicated that significant increase in $\mathrm{P}$ uptake due to the effect of seed priming in P solution. Similar results were also found by [33] who indicated that significant increase in $\mathrm{Zn}$ uptake by seedling due to nutrient priming.

Table 3. Grains $\operatorname{cob}^{-1}$, thousand grains weight harvest index and total uptake of nitrogen of maize as influenced by seed priming and different nitrogen levels.

\begin{tabular}{|c|c|c|c|c|}
\hline $\begin{array}{l}\text { Nitrogen } \\
\left(\mathrm{kg} \mathrm{ha}^{-1}\right)\end{array}$ & Grains cob $^{-1}$ & $\begin{array}{l}1000 \text { grain } \\
\text { weight (g) }\end{array}$ & $\begin{array}{l}\text { Harvest index } \\
\text { (\%) }\end{array}$ & $\begin{array}{l}\text { Nitrogen } \\
\text { uptake(\%) }\end{array}$ \\
\hline 0 & $356 \mathrm{c}$ & $252 \mathrm{c}$ & $28 \mathrm{c}$ & $74 c$ \\
\hline 75 & $393 b$ & $277 b$ & $33 b$ & $129 \mathrm{~b}$ \\
\hline 150 & $423 \mathrm{a}$ & $290 \mathrm{a}$ & $34 \mathrm{a}$ & $201 \mathrm{a}$ \\
\hline L.S.D.0.05 & 2.02 & 2.1 & 0.306 & 0.306 \\
\hline Seed priming & - & - & - & - \\
\hline No priming & $371 \mathrm{c}$ & $265 c$ & $30 \mathrm{c}$ & $112 \mathrm{c}$ \\
\hline Water priming & $396 \mathrm{~b}$ & $274 b$ & $31 \mathrm{~b}$ & $138 \mathrm{~b}$ \\
\hline $\mathrm{P}$ priming & $404 a$ & $281 \mathrm{a}$ & $33 a$ & $155 \mathrm{a}$ \\
\hline
\end{tabular}

Mean followed by different letters in each column are differ from each other significantly NS=nonsignificant.

“*” = Significant at 0.05 percent 


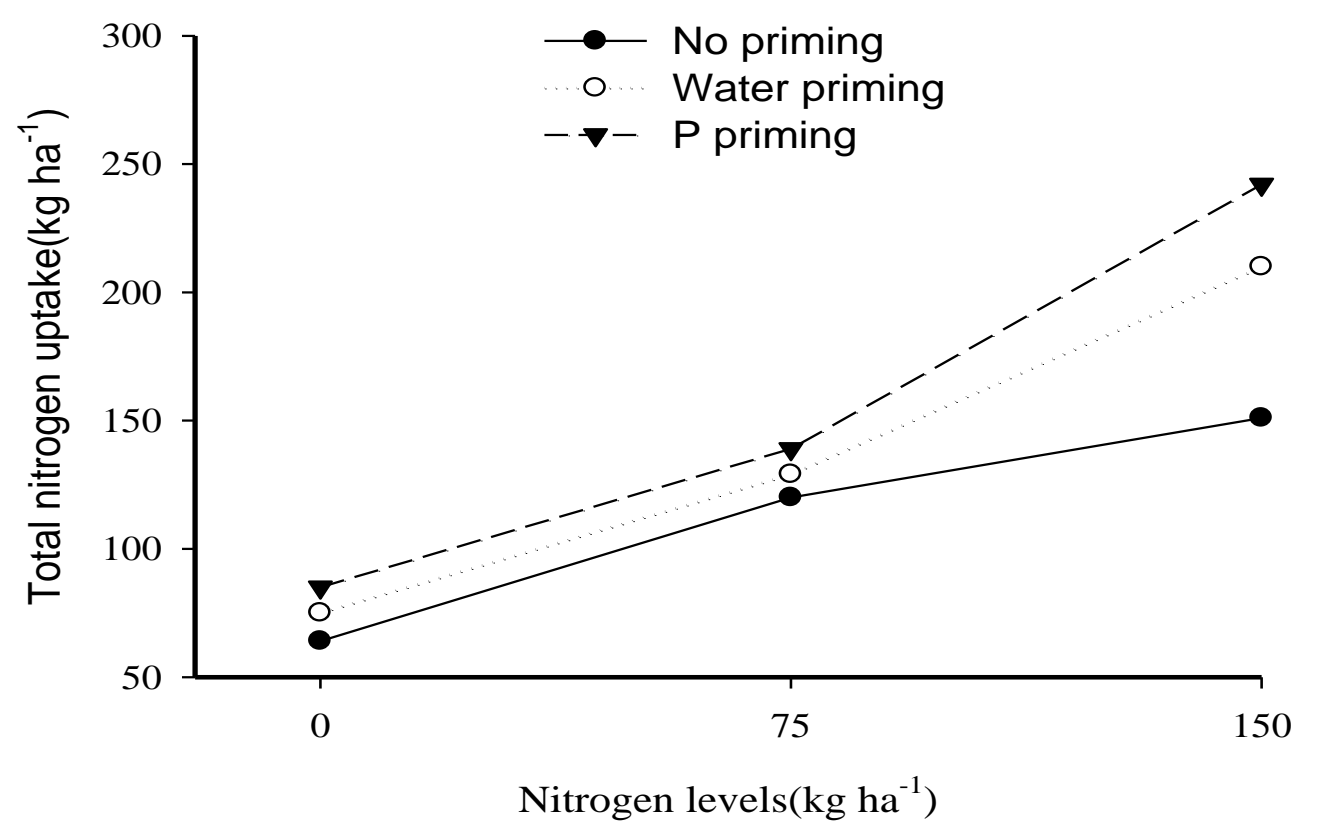

Figure 4. Interactive effect of nitrogen levels and seed priming on maize nitrogen

\section{Conclusions and recommendations}

Application of nitrogen at the rate of $150 \mathrm{~kg}$ $\mathrm{ha}^{-1}$ improved yield and yield component as compared to other levels. Similarly, Phosphorous primed seed produced higher yield and yield component and $\mathrm{N}$ uptake as compared to water soaked and dry seed. Nitrogen application at the rate of $150 \mathrm{~kg} \mathrm{ha}^{-}$ ${ }^{1}$ in split dose along with $0.2 \%$ of $\mathrm{P}$ solution seed priming could be recommended to the farmers for improved maize yield and $\mathrm{N}$ uptake.

\section{Authors' contribution}

Conceived the idea: M Ali, Collected data: Z Ullah, Statistical analysis: IA Mian, Performed statistical analysis: N Khan, N Khan, M Adan \& M Saeed, Wrote the paper: Z Ullah.

\section{References}

1. Khan s \& khalil SK (2007). Effect of seed priming with phosphorus concentration and application rates on wheat. M.Sc (Hons) thesis, Dept. of Agronomy, NWFP Agricultural University Peshawar.
2. Anonymous (2015). Area and production of major crops, Federal Bureau of Statistics, Statistics division, Government of Pakistan.

3. Kessel CV, Pennock DJ \& Farrel RE (1993). Seasonal variation in denitrification and nitrous oxide evolution at the landscape scale. Soil Sci Soc Am J 57(4):988-995.

4. Bould C, Hewitt EJ \& Needham P (1984). Diagnosis of Mineral Disorders in Plants. Vol. 1: Principles. Chemical Publishing, New York.

5. Brady NC (1984). The nature and properties of Soils. Macmillan Publishing Company, New York, pp: 152-158.

6. Sezer I \& Yanbeyi S (1997). Plant density and nitrogen fertilizer effect on grain yield, yield components and some plant characters of popcorn in Carsamba plain. Turkey II. Field crops congress, 22-25 September 1997. Samsun, pp. 128-133.

7. Galloway JN, Schlesinger WH, Levy H, Michaels A \& Schnoor JL (1995). Nitrogen fixation-anthropogenic 
enhancement environmental response. Glob Biogeochem Cycl 9: 235-252.

8. Harris D, Joshi A, Khan PA, Gothkar P \& Sodhi PS (1999). On farm seed priming in semi arid agriculture: development and evaluation in maize, rice and chickpea in India using participatory methods. Exp Agric 35: 15-29.

9. Arif M, Jan MT, Marwat KB \& Khan MA (2007). Seed priming improves emergence and yield of Soybean. Pak J Bot 40(3): 1169-1177.

10. Iqbal \& Ashraf M (2006). Ann Bot Fennici 43: 250-259.

11. Ghana SG \& Schillinger WF (2003). Seed priming winter wheat for germination, emergence, and yield. Crop Science. 43: 2135-2141.

12. Subedi DK \& Ma BL (2005). Seed priming does not improve corn yield in a humid temperate environment. Agronomy Journal 97: 211-218.

13. Ali S, Khan AR, Mairaj G, Arif M, Fida M \& Bibi S (2008). Assessment of different crop nutrient management practices for yield improvement. Aust $J$ Crop Sci 2(3):150-157.

14. Jan MT, Shah P, Hollington PA, Khan MJ \& Sohail Q (2009). Agriculture Research: Design and Analysis, A Monograph. NWFP Agricultural University Peshawar, Pakistan.

15. Khan HZ, Iqbal S, Iqbal A, Akbar N \& Jones DL (2011). Response of maize varieties to different levels of nitrogen. Crop Environ 2: 15-19.

16. Cox WJ, Kalonge S, Cherney DJR \& Reid WS (1993). Growth, yield, and quality of forage maize under different nitrogen management practices. Agron J 85: 341-347.

17. Basra SMA, Farooq \& Khaliq A (2003). Comparative study of pre- sowing seed enhancement treatments in fine rice (oryzasativa L.). Pak J Life Soc Sci 1:5-9.
18. Rashid A, Harris D, Hollington PA \& Khattak RA (2002). On-farm seed priming: a key technology for improving the livelihoods of resource-poor farmers on saline lands. Prospects for saline Agric 6:423-431.

19. Karasu A (2012). Effect of nitrogen levels on grain yield and some attributes of some hybrid maize cultivars (Zea mays indentataSturt.) grown for silage as second crop. Bulg J Agric Sci 18: 42-48.

20. Ghosh DC, Mandal BP \& Malik GC (1997). Growth and yield of wheat (Triticumaestivum L.) as influenced by fertility level and seed-soaking agrochemical. Ind J Agric Sci 67(4): 144-146.

21. Harris D, Rashid A, Arif M \& Younas M (2004). Alleviating micro nutrient deficiencies in alkaline soils of North West Frontier Province of Pakistan: on form seed priming with zinc and wheat and chickpea. An international workshop on Agricultural Strategies to Reduce Micronutrient Problems in Mountains and other Marginal Areas in South and S. E. Asia. Kathmandu Nepal Agricultural Research Council.

22. Patel JB, Patel VJ \& Patel JR (2006). Influence of different methods of irrigation and nitrogen levels on crop growth rate and yield of maize (Zea mays L.). Indian J Crop Science 1(1-2): 175177.

23. Miraj G, Shah HU \& Arif M (2013). Priming maize seed with phosphate solutions improves seedling growth and yield. J Anim Plant Sci 23(3):893 - 899.

24. Ali MA, Sarwar G \& Azad-un-Dollar (1999). Effect ofwater stress on the growth features of different maizecultivar. Pak J Bot 31: 455-460.

25. Alam MM, Muriith F \& Islam MN (2003). Effects of sulfur and nitrogen on the yield and seed quality of maize (cv.Barnali). J Bot Sci 3: 643-654. 
26. Moosavi SG (2012). The effect of water deficit stress and nitrogen fertilizer levels on morphology traits, yield and leaf area index in maize. Pak $J$ Bot 44(4): 13511355.

27. Akmal M, Rehman H, Farhatullah, Asim M \& Akbar H (2010). Response of maize varieties to nitrogen application for leaf area profile, crop growth, yield and yield components. Pak J Bot 42(3): 1941-1947.

28. Zubair M, Bakhat J, Shafi M \& Khan MJ (2009). Effect of methods and levels of nitrogen application on wheat varieties. MSc (hons) thesis, Deptt Of Agronomy, Agri Uni Peshawar. PP 43-44.

29. Akhtar MM (2001). Effect of varying levels of nitrogen on growth and yield performance of two new wheat cultivars. M.Sc (Hons) thesis, Department of
Agronomy, Uni of Agri Faisalabad. PP: 84-86.

30. Bakht J, Shah R, Shafi M \& Khan MA (2010). Effect of various priming sources on yield and yield components of maize cultivars. Pak J Bot 42(6): 4123-4131.

31. Shatab \& Khan S (2007). The effect of priming and $\mathrm{P}$ levels on wheat crop. MSc (hons) thesis, Deptt Of Agronomy, Agri Uni Peshawar. Pp. 53-54.

32. Asokan S, Murthti AN \& Mahadevaswamy M (2005). Effect of nitrogen levels and row spacing on yield, ccs and nitrogen uptake in different in different sugarcane varities. J sugar Tech 7(2,3): 44-47.

33. Slaton NA, Wilson Jr CE, Ntamatungiro S, Norman RJ \& Boothe DL (2001). Evaluation of zinc seed treatments for rice. Agron J 96:152-157. 